\title{
VÝVIN KULTÚRY SLOVENSKA V RÁMCI STREDNEJ EURÓPY A ROLA KRESŤANSTVA V 20. STOROČÍ (PRINCÍPY DEMOKRACIE A KRESŤANSKÉHO UNIVERZALIZMU V KLLUCCOVÝCH LITERÁRNYCH DIELACH)
}

\author{
MÁRIA BÁTOROVÁ
}

BÁTOROVÁ, Mária: Development of the Culture of Slovakia Within Central Europe and the Role of Christianity in the 20th Century (Principles of Democracy and Christian Universalism in Key Literary Works), 2019, Vol. 1, Issue 1, pp. 5 - 11. DOI: 10.17846/CEV.2019.01.1.5-11.

\begin{abstract}
The study has a cross-sectional ambition to point to two socio-political attributes of Slovak culture: Christianity and democracy, from the beginning to the present and on the basis of literary works and their contexts. The Christian motives and the tendency towards equality and democracy in the fight for the rights of Slovak culture are a long-term companion sign of the development which is evident in the artistic expressions of Slovak culture.
\end{abstract}

KEYWORDS: Culture. Literary Work. Central Europe. Christian Universality. Democracy.

V predmetnej štúdii sa budeme zaoberat vývinom slovenskej literatúry a kultúry, poukážeme na špecifiká z hladiska kontextu, ktorým je stredná Európa, na kontext historický a pojem demokracie v ňom, ako aj náboženský a pojmy milosrdenstva, akceptácie zákona, spravodlivosti a rovnosti medzi lud’mi ako klúčových pojmov. Na explikáciu problematiky využijeme vlastný doterajší výskum, v ktorom sme počas desatročí v rôznych výskumných projektoch kládli dôraz na v tejto štúdii zvolené výskumné entity. Pôjde o proces zachytený cez konkrétne literárne diela a ich interpretácie. Textové analýzy obmedzíme kvôli odporúčanému priestoru štúdie prevažne na poéziu - analýzy výňatkov z textov. Prozaické texty prevažne budú prezentované cez konklúzie citovaných monografií, v ktorých sa dajú podrobne overit'.

Stredná Európa je zvláštny priestor, ktorý charakterizuje prienik viacerých kultúr naraz. Nepokojné, nestále a dynamické prostredie. Od pradávna cez toto územie prechádzali obchodné cesty a trasy, v 3. a 2. tisícročí pred Kr. sú doložené kontakty s oblastou Eurázie (západná Sibír a SZ Kazachstan) vrátane severného Kaukazu. Svedčia o tom nielen metalurgické výrobky z medi a bronzu, ale aj protourbánna zástavba, ktorá sa vdaka týmto kontaktom objavuje na našom území (na Slovensku máme doložené vo Vrábloch na hornom Požitaví najstaršie mesto v strednej Európe, staré 4000 rokov). Týmto priestorom viedla významná trasa - tzv. jantárová cesta. Jej prostredníctvom sa jantár dostával zo severu, z oblasti Baltského mora, až do starovekých Mykén vo východnom Stredomorí. O význame tohto regiónu svedčí mimoriadne vel'ký počet kultúr, ktorých iba $\mathrm{v}$ staršej dobe bronzovej tu bolo až 10 (len na porovnanie v oblastiach západne od našich hraníc boli v tomto období iba 3 kultúry). V najnovšej knihe o strednej Európe (Mitteleuropa Revisited, Viedeň, 2018) dvaja Viedenčania, profesori Emil Brix a Erhardt Busek, ktorí sa desatročia pokúšajú charakterizovat tento priestor, vidia strednú Európu ako priestor stretu kultúr a náboženských tradícií, kde je charakteristickým prvkom rozličnost’ a tradične aj tolerancia a pripravenost' na dialóg. Práve po nej volajú dnes, ked’ sa tolerancia k inakosti v našom priestore stráca, a tým stredná Európa odchádza od jednej zo svojich tradičných charakteristík.

Slovensko je v tomto priestore nápadné mnohorakostou, nielen mentálnou (vyplývajúcou z kultúrnych stretov, pripravenostou prispôsobenia a zároveň rezistencie), ale aj mnohorakostou prírodných kontrastov na malom priestore (zásoba pitnej vody, nerastné bohatstvá, velhory aj úrodné pridunajské nížiny). Krajina vlastní všetko potrebné pre život, a preto je aj vždy centrom 
pozornosti - agresie ostatných krajín. Hoci zažila vo svojej histórii pät hegemónií rôznej kvality a intenzity, má schopnost revitalizácie. Kultúra tejto krajiny je otvorená, taký je aj jazykový a myšlienkový systém. Krajina vel’a vždy prijímala, ale intelektuáli z nej pochádzajúci aj vela dali okolitým kultúram svojou činnostou a dielami (Matej Bel, Juraj Szelepcsényi, A. F. Kollár, Ján Kollár, P. J. Šafárik, Š. Moyzes, F. Mikovíny, J. Murgaš, Š. Banič, A. Stodola...).

Integráciu kultúry udržuje špecifický jazyk a územie, na ktorom sa používa, kultúrna produkcia, ktorá na tomto území vznikala a udržiavala sa akoby napriek všetkému. Je obdivuhodné, že nezanikla. Nitra, jedno z najstarších miest v strednej Európe, bola jedným z dvoch bazálnych sídiel Velkej Moravy, kde vznikla prvá škola staroslovienčiny, ktorú priviezli z gréckeho Solúna dvaja intelektuáli filozof Cyril a právnik Metod na žiadosṫ panovníka Rastislava v r. 863. Nový liturgický a kultúrny jazyk - staroslovienčinu - uznal pápež Hadrián za 4. kultúrny jazyk popri gréčtine, hebrejčine a latinčine. Stalo sa tak po slávnej obhajobe Konštantína Cyrila pred pápežom, ked’ obhajoval staroslovienčinu proti trojjazyčníkom slovami Písma: „Na všetkých svieti slnko rovnako...!“ Tu, v tomto bode, teda v krestanstve a v princípoch Nového zákona, vidíme aj korene našej demokracie - rovnosti, ku ktorej sa vraciame a o ktorú sa v priebehu dejín opierame, ked' obhajujeme svoje ludské a občianske práva. Prvá báseň v staroslovienčine Proglas je unikátna vo svojom čase vzniku, ked' medzi bojmi o trón, hladaním sv. Grálu, kameňa mudrcov a legendami o láske, v nej ide o Boha, vzdelanie, knihy, myšlienky.

Každý akt útlaku kultúry, teda proti ludským právam a demokracii na tomto území, vzbudil protitlak a priebežne vznikali „obrany“ jazyka v alternatívnych podmienkach, čiže popri oficiálnych kultúrnych činoch. Alternatívna existencia je jedným z klúčových termínov vývinu slovenskej kultúry. Ani jedna z okolitých kultúr sa nemôže prezentovat v takej miere alternatívnou existenciou kultúry. V tomto je slovenská kultúra jedinečná. Aké sú jej znaky môžeme sledovat po stáročia dozadu. Spomeňme len prípravu prvej kodifikácie slovenského jazyka - Bernolákov Slovár pätjazyčný, 1787, druhú Štúrovu kodifikáciu 1843 - 1846, založenie Matice slovenskej a troch gymnázií, v ktorých sa upevnila aspoň na čas - do r. 1875, ked’ boli zase zastavené oficiálnou vládnou mocou - identita slovenskej kultúry, dalej jej silnejúca asimilácia po rakúsko-uhorskom vyrovnaní v r. 1867/68 a rozkvet po r. 1918, t. j. po vzniku Československej republiky. Politicky výrazne súvisí tento vznik s dvomi menami Milan Rastislav Štefánik (ústredná postava vzniku ČSR) a Andrej Hlinka (kňaz a politik, zaslúžil sa o sociálny systém ešte pred r. 1918), ked' mohla existovat' vo vlastnom jazyku, nebývalé posilnenie kultúry v roku 1938 - 1945, jej ústup do alternatívnej existencie 1948 - 1956, znova rozkvet v 60. rokoch 20. storočia, ked” sa prejavili idey demokracie otvorene v politike Dubčekovej metafory „socializmu s ludskou tvárou“, ktorá sa pretavila do „Pražskej (nie bratislavskej) jari“. Alternatívna bola aj celá disidentská činnost’ tajnej cirkvi na čele s tajne vysväteným biskupom J. Ch. Korcom, ktorá vyústila do sviečkovej manifestácie v roku 1988 a bola začiatkom revolúcie roku 1989. Medzi týmito udalostami sa nachádza paradoxný oficiálny čin prezidenta G. Husáka, ktorý mal zásluhy na zriadení Slovenskej cirkevnej provincie v decembri 1977, čo znamenalo osamostatnenie sa rímskokatolíckej cirkvi v rámci štátnych hraníc (dovtedy patrila do Ostrihomskej provincie). Mimoriadne húževnato sa pestovala tradícia „činu“v slovenskej kultúre, čo pramení tiež v krestanstve a dostalo sa do povedomia znova cez L. Štúra. Generácie kňazov, katolíckych a evanjelických, stavali na pozitívnom čine svoje pôsobenie - sociálnu, kultúrnu či literárnu misiu.

Osmičkové výročia: treba si uvedomit, že každý z tých rokov (1918, 1938, 1948, 1968, 1988/9) je len vyvrcholením procesu, ktorý k nim viedol a že na tom procese sa umenie svojím velkým dielom 
podstatne zúčastňovalo. ${ }^{1}$ Zameriame sa teda na klúčové literárne diela - činy, diela - udalosti, ktoré prispeli k demokratizácii a spoločensko-politickým obratom v osmičkových rokoch.

Literárne reflexie slovenskej situácie by sme mohli väčšinou v dielach kňazov, katolíckych aj evanjelických, sledovat minimálne od 17. storočia $\mathrm{v}$ obranách jazyka a intenzívne od počiatku osvietenstva, teda po vyhlásení reforiem - tolerančného patentu Jozefa II., v Kuzmányho Hronke (žije najmä jeho hymnická pieseň Kto za pravdu horí), u Š. Moyzesa, v Štúrovej škole, v ideovo-estetických polemikách otcov a synov v almanachu Napred, vo vydaní ilustrovaného Učeného tovarišstva 1881 (3 diely esteticky kvalitne ilustrovanej vedeckej činnosti slovenských intelektuálov (F. Oswalda, A. Kmet’a, T. Milkina a i.) na počest’ Bernolákom založeného spolku toho istého mena, a to v čase asimilácie Horného Uhorska zo strany Uhorska. Počas vstupu Apponyiho zákonov do platnosti na školách Horného Uhorska (1909 - 1918) boli napísané v roku 1914, teda na počiatku 1. svetovej vojny, Krvavé sonety, ktoré sú našou vstupenkou do modernej demokracie dodnes. Hviezdoslav mohol túto slávnu báseň publikovat až po roku 1919 v nakladatel'stve B. Kočího v Prahe a skladba bola hned' preložená do mnohých jazykov.
A národ oboril sa na národ
s úmyslom vraždy, s besom skazitela.
Kres spráskal pušiek, zahrmeli delá:
zem stene, piští vzduch, rvú vlny vôd,
kde bleskom kmitla hrozná Astarot.
A jak v žne postat zbožia líha zrelá
pod kosou, radom válajú sa telá;
$v$ cveng šabiel 's splachce čerstvej krvi brod...
Tak vo víchrici totej ukrutenstva,
nímž ani tiger dravšie nezúri,
zapadá nie zvlek: výkvet človečenstva,
života radost' smrtnej do chmúry,
$v$ prach purpur všeludského dôstojenstva,
$v$ sutiny jasný palác kultúry!...

Tieto verše sa nachádzajú v prvej časti skladby (32 sonetov), hned’ za úvodom o krvi ako kvapaline nevyhnutnej pre život človeka a hovoria o smrti, ktorá sa stáva klúčovým motívom. Hviezdoslav postavil tieto dve možnosti život - smrt' ako alternatívy, ako predmet otázky, úvahy a rozhodovania. Kedže horúčkovité zbrojenie a príprava vojsk na prvú svetovú nezmyselnú apokalypsu boli skoro okamžité, priebeh tejto svetovej udalosti charakterizuje expresia výrazov (oboril sa, s besom, zahrmeli, stene, piští, rvú, šplachce, zvlek, dravšie nezúri...) a dynamika (s besom, v žne postat zbožia líha pod kosou, radom válajú sa telá...). Všeobecné konštatovanie agresie („,... A národ oboril sa na národ s úmyslom vraždy...") a abstraktný pojem národ, sa v dalšom mení na konkrétnejšie - telá, ktoré padajú v smrti (pod kosou). Kosa tu má dualitný význam - používa sa v žatve na zožatie žita ako podkladu pre poživeň - chlieb. Tenzia život - smrt’ sa tu znova v paradoxnom obraze opakuje. Básnik sa v d’alších strofách pýta na pôvod tejto hroznej vojny: „Kto zapríčinil tento úpadok, / zosurovenie, zdivočenie mravov? / o ludstvo zviedlo s ducha veličavou /

K otázkam vývinu, chronológii, smerom a žánrom pozri bližšie: Bátorová, Mária, 2007. Kontinuita a diskontinuita literárneho procesu. In: Svět literatury. Časopis pro novodobé literatury, 17/35, 150 - 154. 
vbŕst do bahna? / Ký upír to a mlok, / z pŕs sajúci mu i dnes žitia mok, / krvožíznivec s večnou záhou žhavou? / Ech, sebectvo! to! ...".

Víchrica - to znamená nekontrolovatel'ný živel (tu autor popiera akékolvek racionálne riadenie frontov a strát na nich) zverských ukrutností („ani tiger..."), človek stráca svoju ludskú podstatu, radost' a iné kladné pocity vymenil za chmáru smrti. Básnik v d’alších veršoch apeluje na krestanstvo, ktoré sa stráca, človek sa neriadi podla jeho zásad: „Krestanstvo tvoje lož je, faloš, mam! / Mlč o pohanoch! zle sa vyhováraš: / čo Tatár, Vandal raz, Hun, hla! to stváraš, / sa v majstra vyučiac ich remeslám." Hviezdoslav vníma kultúru ako „jasnú“ - svetlú, teda nesúcu svetlo a „vyššiu“, "dôstojnú“. A táto sa práve ničí a premieňa sa na prach, teda na nehodnotu. Iste bolo o tejto skladbe napísané už dost', no $\mathrm{z}$ nášho výskumného pohladu v tejto štúdii je dôležité vidiet', ako autor kladie otázky a ako na ne odpovedá z etického krestanského hladiska, ktoré prepája na civilizačný proces, stavbu kultúry a vývin človeka v koncepčných rámcoch krestanskej etiky.

Rok 1918 je medzníkom, ktorý umožňuje diferenciáciu kultúrnych úsilí, „otvorenie okien“ do Európy, striedanie a vznik literárnych a umeleckých smerov. Možnost’ konečne hovorit a tvorit’ vo vlastnom jazyku, umenie oslobodené od apologetických „povinností umožňuje kňazom zaoberat sa vlastnou prácou. Len niektorí (Š. Krčméry, M. Rázus, E. B. Lukáč, básnici tzv. katolíckej moderny a i.) nadalej tvoria popri svojom povolaní. Medzivojnová literatúra sa vyznačuje silnými individualitami v umení, aj literárnom. Z predvojnovej generácie okrem Hviezdoslava k 1. svetovej vojne zaujíma literárnym dielom postoj zakladatelka slovenskej moderny v próze B. S. Timrava, ked' vydáva rozsiahlu prózu s ironickým názvom Hrdinovia, Milo Urban v románe nazvanom obrazne Živý bič, v poviedkach so silným etickým a náboženským pátosom, Ján Hrušovský expresionistickým románom Muž s protézou a Gejza Vámoš zvláštnou úvahou o obeti lekárskeho povolania v naturalistickom románe Atómy Boha a na prahu druhej svetovej vojny so skúsenostami z prvej v románe Pisár Gráč aj J. Cíger Hronský, ktorý priamo z gymnázia odchádza na taliansky front na konci prvej svetovej vojny. Sociálny motív tvorí jednu z najsilnejších línií významovej kontinuity slovenskej poézie, prózy a drámy. Ide nielen o diela Fraňa Krála, mapujúce situáciu jednej z najslabších skupín - detí, alebo P. Jilemnického, zachytávajúceho situáciu robotníctva a jeho boj - štrajky za ludské práva, ale aj otázku prostitúcie, služobnosti (Vámoš, Hronský, Novomeský a i.). Utrpenie a súcit $s$ ním, teda základná parola Nového zákona, milosrdenstvo sú stálou súčastou kultúrneho a literárneho vedomia slovenskej moderny (aj výtvarnej, najextrémnejšie v dielach Kolomana Sokola, I. W. Krála a i.). V úvode erbového románu slovenskej moderny Jozef Mak (1933) kráča Kristus svitaním, do ktorého sa narodil človek - milión a prináša mu utrpenie, ako súčast života - kríža. Rezolúcia Kongresu slovenských spisovatelov z roku 1936 v Trenčianskych Tepliciach poukazuje explicitne na stmelenost’ a jednotu slovenských spisovatelov v týchto základných otázkach demokracie a etických i sociálnych princípoch.

Rok 1938 - Mníchovskú „dohodu“ poeticky - básňami komentovali slovenskí básnici skoro korporatívne v dvoch vydaniach za sebou (!) zborníka Pred ohnivým drakom, ktorý editoval E. B. Lukáč.

Janko Jesenský, ktorý v 38. roku naposledy publikoval v Slovenských pohladoch vedených Andrejom Mrázom báseň Tyran aj báseň Návrh, sa potom stiahol do ilegality a jeho básnický politický denník prichádzal z Londýna cez rozhlas recitovaný V. Clementisom. Jesenský básnicky komentoval Mníchov v básni Návrh: 
Vývin kultúry Slovenska v rámci strednej Európy a rola krest’anstva v 20. storočí (princípy demokracie a krestánského univerzalizmu v klúčových literárnych dielach)

\begin{abstract}
Ak jedno námestie nám zostane
alebo kúštik miesta $v$ promenáde

pošlime na sochárov vyzvanie

nech vystavia tam sochu Zrade
\end{abstract}

(v Bratislave 9. októbra 1938, v Slovenských pohladoch v októbri 1938)

Vo všetkých básnických komentároch z vnútornej emigrácie napísaných v tomto čase je znak Jesenského - irónia - ostrý a pregnantný, takže diagnostikuje politické pomery doma aj v Európe. Autonómiu a predpoved' - charakteristiku - vzniku Slovenskej republiky zachytil básňou Tyran (4. číslo Slovenských pohladov, 1938), v ktorej charakterizoval situáciu na Slovensku: „Drúk zostal zo zástavy / z volnosti invalid“. Básne ostatných básnikov (A. Žarnova, V. Beniaka, F. Krála, P. G. Hlbinu a R. Dilonga, J. Kostru, P. Horova, E. B. Lukáča...) sa rovnako vzpierajú cudzej politickej tyranii. $^{2}$

Jesenského básne z tohto času boli konkrétnym politickým denníkom tých čias. Dokladajú to citáty z denníkov uvádzaných ako mottá v básňach. Tak ostrou kritikou zasiahol napríklad aj slovenskú vojenskú účast’ na tažení proti Polsku v básni Pri páde Varšavy (Bratislava 29. septembra 1939) (Jesenský 1977, 553).

Slovenské povedomie demokracie a mnohonásobná básnická evidencia nastupujúceho útlaku svedčia o tom, že slovenská literatúra a kultúra sa v kvalitnej poézii, próze, publicistike (L. Novomeský: Nelúčenie, Elán 1939; M. Figuli: Olovený vták, Slovenské pohlady 1940 a román J. C. Hronský Pisár Gráč, 1940) postavila jednohlasne za demokratické princípy, nový štátny útvar považovala za nanútený, nátlakový a nedemokratický.

Dominik Tatarka, ktorý debutoval počas Slovenskej republiky poviedkami $V$ úzkosti hladania (1942), naozaj hladal svoju cestu, pretože bol vychovaný v prísnom katolíckom duchu a zažil aj občiansky postoj slobodných Parížanov na štúdiách v Sorbone v roku 1938/39 (situáciu toho času a vlastný strach o demokraciu vo vlasti nachádzame v neskoršie vydanej próze Prútené kreslá). Ked’ vzniká slovenský štát, okamžite sa vracia domov, pôsobí v slovenskej kultúre, učí na gymnáziách v Žiline a Martine, odchádza do povstania, a to všetko sú jeho náhle rozhodnutia v úzkostiach hladania. Záznam z týchto hladaní za Slovenskej republiky predstavuje román Farská republika, ktorý za socializmu zneužívali ideológovia ako kritiku slovenskoštátovského školstva, perzekúcie židovského obyvatel'stva, konvenčnej krestanskej morálky. Nechceli si všimnút, že autor kritizoval aj komunistické praktiky. Tatarka vydal v 50. rokoch 20. storočia tri romány, v ktorých sa mal ukázat ako autor metódy socialistického realizmu (Prvý a druhý úder, Radostník, Družné letá). Ak však porovnáme príkladné dielo tejto umeleckej metódy Drevená dedina od F. Hečka s dielami Tatarku, zistíme, že Tatarkove diela túto metódu ani zdaleka v úplnosti nesplňajú (Bátorová 2017, 7 - 30).

Rok 1947/48 je per negationem a paradoxne zvonka, z Ríma, charakterizovaná situácia na Slovensku vo vel'kej alegórii románu Andreas Búr Majster. ${ }^{3}$

Tatarkova esej Démon súhlasu (Kultúrny život, 1956) sa spolu s ostatnými esejami po Stalinovej smrti (C. Milosz: Zotročené storočie, Londýn 1953, P. Kohout: Septembrové noci, Praha 1954) stala udalostou v dejinách literatúry, pretože Tatarka presne popísal metódy ideologického teroru 50. rokov, ktoré sám zažíval v 50. rokoch 20. storočia. Rovnako rok 1968 treba považovat za predstupeň

2 K poézii roku 1938 podrobne pozri v knihe Bátorová, Mária, 1992. Roky úzkosti a vzopätia. Bratislava: Causa editio, 43 - 51 .

3 Pozri bližšie Bátorová, Mária, 2000. J. C. Hronský a moderna. Mýtus a mytológia v literatúre. Bratislava: Veda, Ústav svetovej literatúry SAV. 
Tatarkovho pohybu k svojmu etickému vrcholu - k devätnástim rokom jeho zamlčanej existencie, čím si vystaval pomník ako slobodný človek a umelec. Koniec 50. a 60. rokov 20. storočia treba považovat za rozmach slovenskej kultúry v zmysle otvorenosti estetickým a filozofickým aj západným smerom, a v tom zmysle znovu aj demokracii v Dubčekovej metafore politického prerodu k socializmu s ludskou tvárou. Slobodný čas prebudil v Tatarkovi potláčanú kvalitu náboženského presvedčenia a estetickej kvality umenia zo štúdií v Prahe a na Sorbone a publikuje v Smene (7. 5. 1968, 3 - 6) rozsiahlu esej Obec božia - obec človečia (v archíve je jeho rukopis nadpísaný názvom Obec Božia). Tu možno koncentrovane čítat demokratické princípy prepojené na krestanský univerzalizmus. Konštatujeme genetickú súvislost’ s dielom A. Camusa a s dielom Civitas dei od sv. Augustína. Princípy Nového zákona - príkladné spolužitie medzi lud’mi ako najvyšší princíp, ako záruka kvalitného života a medziludských vztahov (Bátorová 2012, 181 - 198). Roky konsolidácie a perestrojky prežíva Tatarka v paralelnej kultúre, vracia štátne vyznamenanie, žije bez pasu a občianskych práv, počas devätnástich rokov si stavia pomník neoblomného protivníka totalitného myslenia. Po prvýkrát sa spomenie jeho meno a dielo na verejnosti v roku 1988 na konferencii Vojna v umení, umenie vo vojne. Autorka tohto príspevku prednesie analýzu Tatarkovej novely Pach (Slovenské pohlady, jún - júl 1943). V máji roku 1988 sa politický prevrat k demokracii začína sviečkovou náboženskou manifestáciou na Hviezdoslavovom námestí. V turbulentnom roku „nežnej revolúcie“, v roku 1989/90, píše autorka tohto príspevku prvú literárnu reflexiu politických udalostí v novele Zvony v kameni (Vydavatel'stvo USPO Peter Smolík, 1993), odmenenú kanadskou cenou Hronský '92.

\section{SUMMARY}

In this study, we have attempted, on the basis of our own long-term research, to cross-referenced and selectively point out the development of the culture of today's territory of Slovakia in the contexts of Central Europe. We have highlighted the specificity of this country - at the certain time more, in another less colonized culture until the establishment of the Slovak Republic in 1993 (Bátorová 2014, $71-85$ ). We have focused on the continuing role of Christianity in shaping and maintaining the identity of Slovak culture, because it is symptomatic for the identity of Central Europe, as the multiplicity and diversity that Christian universalism accepts. Christian universality has consistently manifested in writers' tolerance and attitudes in Slovak literary works, encouraging them to adhere to ethical standards that were the subject of criticism by Slovak writers, when they were violated in practice. As the issue of democracy is also related to Christian universality and colonization of culture, we have pointed to the genesis of this important political concept and its permanent functioning in practice, which confirms today's living reality.

By the explication of such difficult developmental issues demonstrated on materials, we used our own model of interpretation (used in research practice since 2000, focusing in addition to text on contexts defined as a model in 2016 at the Vienna Congress of Comparatives (Bátorová 2016). It is based on the communication formula $\mathrm{A}-\mathrm{T}-\mathrm{R}$ (Nitra's school), but each of the members of this formula is associated with the studied contexts: historical, sociological, philosophical, psychological, psychoanalytic and other. Each analysed text is also a verifier of the correctness of the interpretation.

\section{LITERATÚRA}

Bátorová, Mária, 2016. „Autor,, ,Text' und ,Leser im Kontext. Komparatistik und Sozialwissenschaften." 21. - 27. júl 2016, Universität Wien (ICLA). Panel Kabinetu Dionýza Ďurišina ÚFŠ (v tlači). 
Bátorová, Mária, 2000. J. C. Hronský a moderna. Mýtus a mytológia v literatúre. Bratislava: Veda, Ústav svetovej literatúry SAV.

Bátorová, Mária, 2007. Kontinuita a diskontinuita literárneho procesu. In: Svět literatury. Časopis pro novodobé literatury, 17/35, $150-154$.

Bátorová, Mária, 1992. Roky úzkosti a vzopätia. Bratislava: Causa editio.

Bátorová, Mária, 2014. Slovak literature and culture from the „postcolonial“ perspective. In: Primerjalna književnost, 37/3, 71 - 85.

Bátorová, Mária, 2017. Socialistický realizmus a jeho podoby v slovenskej literatúre (Tvorba Dominika Tatarku a Františka Hečka v 50-tych rokoch 20. storočia). In: Bátorová, Mária (ed.): Socialistický realizmus v literatúrach strednej Európy. 27/1, 7 - 30.

Bátorová, Mária, 2012. Dominik Tatarka - slovenský Don Quijote. Bratislava: Veda.

Hviezdoslav, Pavol Országh, 1952. Krvavé sonety. Martin: Matica slovenská.

Jesenský, Ján, 1977. Poézia I. Bratislava: Tatran.

\section{KONTAKT}

prof. PhDr. Mária Bátorová, DrSc.

Ústav svetovej literatúry SAV Bratislava

Konventná 629/13

81103 Bratislava

a

Pedagogická fakulta UK Bratislava

Račianska 59

81334 Bratislava

Slovenská republika

maria.batorova.sav@gmail.com 